\title{
Atrial fibrillation after ondansetron for the preven- tion and treatment of postoperative nausea and vomiting: a case report
}

\author{
[Fibrillation auriculaire causée par l'ondansétron administré pour prépenir et \\ traiter les nausées et les vomissements postopératoires : une étude de cas]
}

Nagesha S. Kasinath MD, Osama Malak MD, John Tetzlaff MD

Purpose: Even though clinical safety has been established in large studies, ondansetron has been reported to cause adverse cardiovascular events. We present a case of atrial fibrillation in association with ondansetron in the postoperative period.

Clinical features: A 47-yr-old, $81 \mathrm{~kg}$ female presented with a benign lump in her left breast for lumpectomy. Her past medical history was unremarkable. Physically she was very active, nonsmoker and had no allergies. She underwent the procedure under general anesthesia. She received $4 \mathrm{mg}$ of ondansetron intravenously for postoperative nausea and vomiting prophylaxis at the end of the procedure and an additional $4 \mathrm{mg}$ in the recovery room for nausea. Within 15 min after the second dose she was noted to be in atrial fibrillation that required admission to the hospital and procainamide infusion for conversion to normal sinus rhythm. She did not have any evidence of myocardial ischemia, valvular abnormality or pulmonary embolism.

Conclusion: The 5-hydroxytryptamine 3 receptor $\left(5-\mathrm{HT}_{3}\right)$ antagonist ondansetron has been reported to cause myocardial ischemia, supraventricular and ventricular tachycardia. Postulated mechanism includes inhibition of Bezold-Zarisch cardiac reflex and coronary vasoconstriction. Inhibition of $5-\mathrm{HT}_{3}$ receptors in the heart could lead to unopposed action of other serotonin receptors leading to atrial fibrillation or other tachyarrhythmias described in the literature.

Objectif : Même si son innocuité clinique a été prouvée par de grandes séries, on a démontré que l'ondansétron peut avoir des effets cardiovasculaires indésirables. Nous présentons un cas de fibrillation auriculaire associée à l'ondansétron en période postopératoire.

Éléments cliniques : Une femme de 47 ans et de $81 \mathrm{~kg}$ a été admise pour l'exérèse locale d'une tumeur bénigne au sein gauche. Son histoire médicale était sans particularité. Elle était très active, non fumeuse et sans allergies. Elle a été opérée sous anesthésie générale. À la fin de l'opération, elle a reçu 4 mg d'ondansétron intraveineux contre les nausées et les vomissements postopératoires et, en salle de réveil, une dose supplémentaire de $4 \mathrm{mg}$ contre les nausées. Moins de 15 min après la seconde dose, une fibrillation auriculaire a nécessité l'admission à l'hôpital et une perfusion de procaïnamide pour rétablir un rythme sinusal normal. Aucun indice d'ischémie myocardique, d'anomalie valvulaire ou d'embolie pulmonaire n'ont été mis en évidence.

Conclusion : On a déjà montré que l'ondansétron, antagoniste du récepteur 5-hydroxytryptamine $3\left(5-\mathrm{HT}_{3}\right)$, pouvait causer de l'ischémie myocardique, de la tachycardie supraventriculaire et ventriculaire. Le mécanisme en cause pourrait être l'inhibition du réflexe cardiaque de Bezold-Jarisch et la vasoconstriction coronaire. L'inhibition des récepteurs cardiaques de $5-\mathrm{HT}_{3}$ peut entraîner une action non compensée d'autres récepteurs de sérotonine provoquant une fibrillation auriculaire ou d'autres tachyarythmies connues.

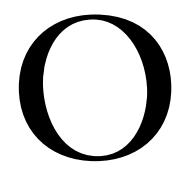
NDANSETRON is a 5-hydroxytryptamine $3\left(5-\mathrm{HT}_{3}\right)$ receptor antagonist used widely in the prophylaxis and treatment of postoperative nausea and vomiting (PONV) and vomiting associated with cancer chemotherapy. Even though its clinical safety has been established in large studies, adverse events have been reported., ${ }^{1,2}$ These include neuro-psychiatric events (dystonic reactions and acute depression) $)^{3,4}$ and cardiovascular events (acute myocardial ischemia, arrhythmias etc.). ${ }^{5,6}$

From the Division of Anesthesiology and Critical Care Medicine, Cleveland, Ohio, USA.

Address correspondence to: Dr. John E. Tetzlaff, Staff Anesthesiologist, Division of Anesthesiology and Critical Care Medicine, E-30, The Cleveland Clinic Foundation, 9500 Euclid Avenue, Cleveland, Ohio 44195, USA. Phone: 216-444-3739; Fax: 216-445-0605; Email: tetzlaj@ccf.org

Accepted for publication June 11, 2002.

Revision accepted November 6, 2002. 
We report a case of postoperative atrial fibrillation in a healthy woman who underwent left partial mastectomy and received ondansetron for the prevention and treatment of PONV.

\section{Case report}

A 47-yr-old, $81 \mathrm{~kg}$ female presented with a benign lump in her left breast for partial mastectomy. Her past medical history was unremarkable. Physically she was very active, a non-smoker and had no known drug allergies. Her physical examination was unremarkable, blood tests were within normal limits and the electrocardiogram (EKG) showed no abnormalities.

She was premedicated with midazolam $1 \mathrm{mg}$ given intravenously outside the operating room approximately $20 \mathrm{~min}$ prior to induction of anesthesia. On arrival to the operating room, standard ASA monitors were applied which included noninvasive blood pressure, continuous pulse oximetry, end-tidal carbon dioxide sampling and continuous 5 lead EKG. General anesthesia consisted of propofol $\left(2 \mathrm{mg} \cdot \mathrm{kg}^{-1}\right)$ for induction, a laryngeal mask airway and isoflurane (1-1.5 MAC) in 70\% $\mathrm{N}_{2} \mathrm{O}$ and $30 \% \mathrm{O}_{2}$ and fentanyl $(150 \mu \mathrm{g})$ for maintenance. She was allowed to breathe spontaneously with intermittent assistance to maintain normocarbia. Ketorolac $30 \mathrm{mg}$ and ondansetron $4 \mathrm{mg}$ were given intravenously approximately $15 \mathrm{~min}$ prior to completion of surgery. The intraoperative period and emergence were uneventful and she was transferred to the postoperative care unit (PACU) for observation. Blood loss was minimal and she received $1500 \mathrm{~mL}$ of Ringer's lactate intraoperatively.

On arrival in the PACU she was nauseous and vomited once. She was uncomfortable and slightly anxious, but pain free. A second dose of ondansetron 4 $\mathrm{mg} i v$ was administered in the PACU $35 \mathrm{~min}$ after the first dose in the operating room. About 15 min later she was found to be in atrial fibrillation with a ventricular rate of $120-130$ beats. $\mathrm{min}^{-1}$. She was hypertensive with blood pressures ranging from 140/80 to $170 / 98 \mathrm{mmHg}$. Her oxygen saturation $\left(\mathrm{SpO}_{2}\right)$ was $97 \%$ on room air and respiratory rate was $16-20$ per minute. Nausea had resolved and she was otherwise completely asymptomatic. A 12-lead EKG confirmed the presence of atrial fibrillation and there were no ST$\mathrm{T}$ changes to suggest myocardial ischemia. The postoperative QTc interval was $419 \mathrm{msec}$ (preoperative value of $413 \mathrm{msec}$ ) and the QRS interval was $88 \mathrm{msec}$ (preoperatively $76 \mathrm{msec}$ ). She received two doses of esmolol $30 \mathrm{mg}$ and two doses of metoprolol $5 \mathrm{mg}$, intravenously without any change in rhythm. A cardiologist was consulted and she was admitted to the telemetry floor for chemical cardioversion. Her serum chemistry showed sodium-138 $\mathrm{mEq} \cdot \mathrm{L}^{-1}$, potassium$4.2 \mathrm{mEq} \cdot \mathrm{L}^{-1}$, calcium-8.7 mg. $\mathrm{dl}^{-1}, \mathrm{Mg}-1.7 \mathrm{mEq} \cdot \mathrm{L}^{-1}$, BUN/Cr-9/0.7 (mg \%). Hemoglobin was 13.5 $\mathrm{g} \cdot \mathrm{dl}^{-1}$. She was started on a procainamide infusion $(2$ $\mathrm{mg} \cdot \mathrm{min}^{-1}$ ) after a loading dose of $10 \mathrm{mg} \cdot \mathrm{kg}^{-1}$ intravenously over $30 \mathrm{~min}$. She converted to sinus rhythm after about $12 \mathrm{hr}$. A two-dimensional echocardiogram showed normal ventricular function, normal atria and valves. She was started on metoprolol $25 \mathrm{mg}$ po bid and procainamide was discontinued. She remained in sinus rhythm and was discharged home the next day with advice to take metoprolol for four weeks.

\section{Discussion}

Although it is clear that a previously healthy patient developed atrial fibrillation shortly after the administration of ondansteron, we cannot conclusively establish ondanstron as the cause. Although other reports establish the $5-\mathrm{HT}_{3}$ receptor antagonists to have some potential for arrythmogenicity, there are a large number of other factors in the postoperative period that can also create atrial fibrillation, including pain, anxiety or even subclinical coronary artery disease. Nonetheless, it is logical to explore the association of the onset of atrial fibrillation with the parenteral administration of ondansteron in this case.

Ondansetron belongs to the group of $5-\mathrm{HT}_{3}$ receptor antagonists used widely in the prophylaxis and treatment of nausea and vomiting following surgery and cancer chemotherapy. Even though its clinical safety has been established in many trials, cardiovascular adverse effects have been reported with the use of ondansetron. Ballard et al., reported ondansetronassociated myocardial events in seven chemotherapy patients, consisting mainly of anginal episodes. ${ }^{7}$ Bosek et al. reported transient myocardial ischemia in a patient who received ondansetron in the intensive care for nausea. ${ }^{5}$ Their patient received only $2 \mathrm{mg}$ of ondansetron and immediately developed severe substernal chest pain, hypertension, EKG changes and had ventricular and supraventricular tachycardia associated with ischemia. All these resolved with a single dose of $0.4 \mathrm{mg}$ of sublingual nitroglycerin. Similarly Baguley reported two cases of myocardial ischemia temporally associated with the administration of ondansetron and metoclopramide. ${ }^{6}$ One patient received $4 \mathrm{mg}$ ondansetron and metoclopramide preoperatively and developed myocardial ischemia immediately. The other patient developed signs of ischemia intraoperatively after receiving metoclopramide $4 \mathrm{mg}$ and ondansetron $2 \mathrm{mg}$ intravenously. The first patient had transient ventricular bigeminy while the second had junctional rhythm progressing to runs of ventric- 
ular tachycardia and then to supraventricular tachycardia with hypertension. Concurrent use of metoclopramide confounded the findings in these two cases, because it is known to enhance catecholamine release, probably by blocking autoreceptors.

It is not known clearly how serotonin receptor antagonists can cause myocardial ischemia in humans. Saxena and Villalon have noted a complex pattern of coronary vasodilation and constriction mediated by 5 HT receptors in many animal species and humans. ${ }^{8}$ The cardiovascular effects of serotonin are complex and consist of bradycardia or tachycardia, hypotension or hypertension and vasoconstriction or vasodilation. ${ }^{9}$ The cardiovascular effects of serotonin are mediated by four types of receptors: $5-\mathrm{HT}_{1}, 5-\mathrm{HT}_{2}, 5-\mathrm{HT}_{3}$, and $5-\mathrm{HT}_{4}$, which are distributed throughout the cardiovascular system. The $5-\mathrm{HT}_{3}$ receptors mediate von Bezold-Zarisch reflex, an autonomic reflex consisting of bradycardia, hypotension and apnea. Inhibition of this reflex has been used to study the potency of 5$\mathrm{HT}_{3}$ receptor antagonists in animals. $5-\mathrm{HT}_{1}, 5-\mathrm{HT}_{2}$ and possibly $5-\mathrm{HT}_{4}$ receptors mediate tachycardia and the hypertensive responses to serotonin. Most of these findings come from animal studies and have yet to be established in humans.

In our patient atrial fibrillation was observed after the second dose of ondansetron. Symptoms of nausea improved and she did not have any cardiac or pulmonary symptoms to suggest myocardial ischemia or pulmonary embolism. She did not receive any other medication during this period except for iv fluid. Atrial fibrillation has rarely been described in association with ondansetron so far, even though tachyarrhythmias are known to occur.

There is no clear explanation of how $5-\mathrm{HT}_{3}$ receptor antagonists cause atrial and ventricular tachyarrhythmias. Bosek et al. postulated that in some individuals, ondansetron and other $5-\mathrm{HT}_{3}$ receptor antagonists, by suppressing cardiac $5-\mathrm{HT}_{3}$ receptors, may result in the inhibition of the Bezold-Zarisch reflex, leading to tachyarrhythmias which, in some cases, may also be associated with coronary vasoconstriction and myocardial ischemia. ${ }^{5}$ We think $5-\mathrm{HT}_{3}$ receptor blockade could possibly result in unopposed action of other receptor subtypes $\left(5-\mathrm{HT}_{2}, 5-\mathrm{HT}_{4}\right)$ resulting in tachyarrhythmias and hypertension. This could possibly explain the tachyarrhythmia and hypertension observed in our case and in other case reports. This may also explain other unwanted effects like headache and neuro-psychiatric events. ${ }^{3,4}$ Minor increases in P-R, QRS and QTc intervals are described with all $5-\mathrm{HT}_{3}$ receptor antagonists in healthy individuals and chemotherapy patients. ${ }^{10,11}$ Kaumann suggested that human sinoatrial $5-\mathrm{HT}_{4}$ receptors may be involved in the genesis of atrial fibrillation and associated thromboembolic stroke and that both arrhythmia and stroke could be prevented by inhibiting $5-\mathrm{HT}_{4}$ receptors. ${ }^{12}$

In conclusion we suspect that ondansetron caused the atrial fibrillation in this case, even though an idiopathic etiology cannot be ruled out. More case reports are required to confirm this observation and the clinical safety of ondansetron.

\section{References}

1 Domino KB, Anderson EA, Polissar NL, Posner KL. Comparative efficacy and safety of ondansetron, droperidol, and metoclopramide for preventing postoperative nausea and vomiting: a meta-analysis. Anesth Analg 1999; 88: 1370-9.

2 Castle WM, Jukes AJ, Griffiths CJ, Roden SM, Greenstreet $Y L A$. Safety of ondansetron. Eur J Anaesthesiol 1992; 9(Suppl 6): 63-6.

3 Tolan MM, Fubrman TM, Tsueda K, Lippmann SB. Perioperative extrapyramidal reactions associated with ondansetron (Letter). Anesthesiology 1999; 90: 340-1.

4 Blaine EM. Acute severe depression following perioperative ondansetron. S Afr Med J 1997; 87: 1013-4.

5 Bosek V, Hu P, Robinson L. Acute myocardial ischemia after administration of ondansetron hydrochloride. Anesthesiology 2000; 92: 885-7.

6 Baguley WA, Hay WT, Mackie KP, Cheney FW, Cullen $B F$. Cardiac dysrrhythmias associated with the intravenous administration of ondansetron and metoclopramide. Anesth Analg 1997; 84: 1380-1.

7 Ballard HS, Bottino G, Bottino J. Ondansetron and chest pain (Letter). Lancet 1992; 340: 1107.

8 Saxena PR, Villalon CM. 5-Hydroxytryptamine: a chameleon in the heart.Trends Pharmacol Sci 1991; 12: 223-7.

9 Saxena PR, Villalon CM. Cardiovascular effects of serotonin agonists and antagonists. J Cradiovasc Pharmacol 1990; 15(Suppl 7): S17-S34.

10 Boike SC, Ilson B, Zariffa N, Jorkasky DK. Cardiovascular effects of i.v. granisetron at two administration rates and of ondansetron in healthy adults. Am J Health-Syst Pharm 1997; 54: 1172-76.

11 Watanabe H, Hasegawa A, Shinozaki T, Arita S, Chigira $M$. Possible cardiac side effects of granisetron, an antiemetic agent in patients with bone and soft-tissue sarcomas receiving cytotoxic chemotherapy. Cancer Chemother Pharmacol 1995; 35: 278-82.

12 Kaumann AJ. Do human atrial 5- $\mathrm{HT}_{4}$ receptors mediate arrhythmias? Trends Pharmacol Sci 1994; 15: 451-5. 